\title{
PACKING DEATH IN AUSTRALIAN LITERATURE
}

\author{
Iris Ralph \\ Tamkang University \\ irisralph@mail.tku.edu.tw
}

\begin{abstract}
In this article, the author identifies critical connections between the transformation of food in the last two hundred thirty years and arguments by animal studies, indigenous studies, ecocriticism, ecofeminism, and environmental history scholars. She does that through a reading of two works of Australian literature: Merlinda Bobis's cli-fi novel Locust Girl and Evie Wyld's post-pastoral fiction All the Birds Singing. Bobis's novel raises questions about the given transformation as it directly relates to the birth of the commercial kangaroo-meat industry, depletion of arable land as a direct consequence of the overuse of it for introduced species of animals reductively called livestock, and obliteration of extensive grain belts in Australia. Wyld's novel addresses the given transformation in an implicit critique of Australia's sheep industry and, by implication, Australia's cattle industry. Both constitute Australian pastoral, which has profoundly transformed food in Australia and eradicated interspecies balances thousands of years old. The novels represent the notice, as limited as that is, in contemporary Australian literature of the radical transformation of food since the late eighteenth century. Illustrating her argument by referring to the two novels, the author argues that literary food studies must reflect greater engagement with ongoing interspecies abuses that define food production. Difficult as those injustices are to confront, they point to the gross moral and material failings in the transformation of food since the late eighteenth century.
\end{abstract}

\section{Keywords}

climate change; dark pastoral; ecological animalism; grain; ontological veganism 


\begin{abstract}
About the Author
Iris Ralph is an Associate Professor in the English Department, Tamkang University, Taipei, Taiwan. She holds a B.Sc. from Monash University, a B.A. (English) from San Francisco State University, and an M.A. (English) and Ph.D. (English) from The University of Texas at Austin. Dr. Ralph's areas of specialization are literature and language, ecocriticism, animal studies, and posthumanism. Her publications include book chapters in Doing English in Asia: Global Literature and Culture (Lexington); Ecocriticism in Taiwan: Identity, Environment, and the Arts (Lexington); Ted Hughes (Palgrave Macmillan); and International Perspectives in Feminist Ecocriticism (Routledge). Other publications include journal articles in Neohelicon; AJE: Australasian Journal of Ecocriticism and Cultural Ecology; Tamkang Review; William Carlos Williams Review; Cowrie; CLCWeb: Comparative Literature and Culture; Forum for World Literature Studies; Journal of Ecocriticism; NTU Studies in Language and Literature; and Concentric.
\end{abstract}


"Packing death" is an expression of fear and anxiety in Australian English. I use the expression in a different yet related sense here to describe the transformation of food in the last two hundred thirty years. The term specifically refers to the animals and plants that corporate capitalist food giants in recent decades have been packing into, and packaging as, food, and the allusions that two works of Australian literature, Evie Wyld's post-pastoral novel, All the Birds, Singing, and Merlinda Bobis's cli-fi novel, Locust Girl, make to that terrific overstuffing and overselling. Wyld implicitly interrogates the intensive farming of sheep for import and export in the form of Australian mutton and lamb products. Bobis obliquely and powerfully critiques the recent kangaroo-meat industry as well as the loss since 1788 of arable land and the obliteration of extensive grain belts-ecosystems that humans coexisted with and relied on for food for millennia in Australia before 1788. Small but powerful corporate capitalist interests have steadily and highly successfully eroded the ethical interspecies bonds between human and nonhuman animal and vegetal life in the name of creating food. I address that food transformation through a reading of Wyld's All the Birds, Singing and Bobis's Locust Girl and by relating that reading to studies published in animal studies, indigenous studies, ecocriticism, ecofeminism, and environmental history. Food and ethics are inseparable. Similarly, how people produce food is inseparable from how they imagine human/nonhuman relationships. Until current food production practices change, it will be impossible to address those relationships. Wyld's and Bobis's novels represent the aesthetic registering of the struggle to change those production practices as well as the critical role that aesthetic texts and other aesthetic sites play in shaping our understanding not only of food but also of our very capacity to envision what ethical relationships are and what they imply. Without such texts, current food production will continue to wheel, or wheel faster, on its morally moribund tracks.

Food transformation today reflects the "unprecedented transformation in the treatment of and thinking about animals" since the end of the nineteenth century (Calarco 108). It has consisted of two separate yet parallel paths: the escalation in "the subjection of animals" and the increase in animal justice and animal advocacy movements (108). The first pathway, which is far outstripping the second, refers to the modern phenomenon of industrial animal food production, or "massive, industrialized, and intensive modes of violence against animals" (113). The second pathway, the "counterforce of animal protection," is manifest in a broad spectrum of movements, activist engagements, and theoretical articulations (113). It is the fight over "the question of violence and compassion toward animals," and it raises the moral stakes around the discourse of food (113). That struggle is an "unequal" and "protracted" one. The reasons have to do with apathy, ignorance, ecophobia, and, above all, corporate capitalist food giants that capitalize on that indifference, lack of knowledge, and fear and hatred of the nonhuman other. Those food 
giants could not otherwise exist and would be modest, sustainable, and morally inoffensive companies. The transformation of food is the control of the world's food by multinational corporate capitalist companies, the "economic colonization" of food by those companies (Robin 311), and their steady obliteration of moral and affective ties between food and plants and animals.

On an immediate narrative level, All the Birds, Singing, shortlisted for the 2014 Man Booker Prize and winner of the 2014 Miles Franklin Literary Award, is not about food transformation. It is also about a woman, Jake Whyte, who is haunted by guilt for a wrong committed as a teenager that led to the deaths of two other teenagers. In addition, it is about a country, personified in the character of Jake, that has been deeply scarred by its racist and genocidal past, that of AngloEuropean newcomers and their violence against Australia's oldest people. On that same level, Jake is also a character through which Wyld alludes to the masculinist ecocidal contours of food transformation in Australia.

A teenager running from and punishing herself for a racist and ecocidal act, partly conscious and partly unconscious (starting a bushfire that kills Denver Cobby, the "half-Aboriginal kid" with whom Jake was infatuated), Jake makes money by selling her body to men (Wyld 215). When she can no longer do that, she finds work as a casual hand and sheep shearer on remote stations in the outback. Jake epitomizes gender and class oppression as well as the collective guilt of white Australia. She also represents food transformation in Australia. That primarily associates with Australian pastoral, which refers to "the work of raising sheep or cattle-as opposed to crops-on the land" (Tredinnick 125). Australian pastoral essentially depends on the government's seizure of environments from their oldest human custodians, the overbearing control of those environments, and the commodification of animals that are intensively farmed in those environments. Australian pastoral in effect allows several animal species to exist solely because they can be commodified, and almost solely because they can be commodified as food. It oppresses those animals, denying them any form of autonomy or agency. Jake represents the embattled bodies of those animals as well as the oppressed bodies of minority human groups.

Otto, a paedophile and misogynist whom Jake lives with for some months, is a figure for the worst aspects of the sheep-meat industry. He beats Jake, bestializes her, and forces her to watch him as he kills sheep. Their cries "rattle [Jake's] bones" (Wyld 93). On one occasion, when Otto forces Jake to watch him as he slaughters an ewe, Jake is torn between protesting the killing and protecting her own body from Otto. He "swings [the ewe] up the ramp in front of him, and she gives out a terrible sound" (93). Jake "[stands]...outside the woodshed, mute [and tackles] the urge to kick down the fence and tell [the other sheep] to flee" (93). When Otto orders Jake to kill a second ewe, "the [one] with the black spots... whipping about 
underneath Otto" and rolling her eyes in fear, Jake complies (95). Otto "is enjoying seeing [her] scared" and "has a hard-on through his shorts" (95). Jake feels her "strong arms [float] from [her] shoulders, as weak as feathers" (95). She kills the ewe to show Otto that she is "stronger than he thinks" but cannot forgive herself for that act of self-interest and punishes herself for it afterwards (95). When Otto demands to have sex with her, she "[lets] him do what he wants with [her], which is everything" (96).

A major export industry (in addition to the kangaroo-meat, beef, and veal export industries), intensive farming of sheep in Australia is deeply implicated in the global "meatification" (Weis 150) of diets as well as the massive exploitation and invisibility of animals in that food transformation. Intensive farming of sheep defines food transformation in Australia-the food economy, agricultural landscape, and culinary culture-between 2018 and 1788, when AngloEuropean newcomers introduced their pastoral enterprises to Australia. ${ }^{1}$ The popular saying that "Australia rode to prosperity and nationhood on the sheep's back" reflects the common belief among Australians that sheep farming brought great wealth to the country (Tredinnick 123). It and other forms of Australian pastoral are manifestly respected traditions. They are "where one will find the fiercest love for and the deepest wisdom about the land" (126). ${ }^{2}$ They also are where one will find the greatest kinds of "wreck" of that land (126).

In "Is there an Australian pastoral?", part of a collection of essays entitled Contrary Rhetoric: Lectures on Landscape and Language, the poet John Kinsella acknowledges the continuing strong claim that Australian pastoral has on the Australian literary and cultural imagination, even for those such as himself who are vegans, despite his and other Australians' increasing awareness of the exploitation of the people, animals, and environments that constitute Australian pastoral. Commenting on the well-known and beloved anonymous nineteenth-century Australian sheep farming ballad, "Click go the shears," he writes, "I am always going to be at odds with what I see as the exploitation of sheep, and yet in many ways shearers are the country people I feel most akin to. They are the singers of the rural spaces" (152). That conflict stamps his poetry and so distinguishes Wyld's novel. Both writers are, to use the words of Kinsella, unable "to celebrate [Australian pastoral] without negativity" (152). Fellow Australian poet and ecocritic Mark Tredinnick distinguishes their kind of pastoral according to the term "post-pastoral." It reflects writers' acute self-conscious awareness of the need to conduct "the business of reconciliation with country and with Indigenous people," to address the shortsighted "experiment in large-scale Western land use" for food export commodities, and to acknowledge the high price that has been paid "for all that tree-felling, for all that overstocking and all that plundering of the rivers and aquifers" (126). 
Australian post-pastoral is similar to the concept of "dark pastoral," an idea inspired in ecocritic Heather I. Sullivan by Timothy Morton's concepts of "dark ecology" and "mesh." Like post-pastoral, dark pastoral,

shatters traditional notions of nature as an aesthetic and isolated site to visit or ignore and replaces this outdated vision of nature with a more ecological and postmodern understanding that engages us in every location, regardless of its color or number of trees, with a physical, bodily inevitability as part of the "mesh" of the world that includes us. (Sullivan, "Nature and the 'Dark Pastoral”" 116)

In other words, dark pastoral and post-pastoral represent the rejection of dominant pastoral's "idealistic, artificial, and falsely harmonious depictions"; depictions "of 'balance' and simplified ecological systems"; "sheer literary artifice... that emerges from a specifically urban perspective"; and prominent role in the "dominant vision of nature in much of our modern techno-industrial culture" (Sullivan, "Dirty Traffic and the Dark Pastoral" 86). Dark pastoral and post-pastoral call for a discourse of "nature" that will account for the "most disheartening [anthropogenic] acts of devastation" of nature in addition to the "most astonishing accomplishments" of humans with nature (87).

The "disheartening acts of devastation" to which Sullivan refers and to which other scholars and writers refer in their discussion of post-pastoral are deeply bound up in food transformation. Wyld's novel casts a post-pastoral and dark pastoral focus on the violence and venality of that food transformation in Australia (in addition to the violence and profiteering in the wool industry) in the context of the intensive farming of sheep for lamb and mutton. ${ }^{3}$ The novel shows the violence of that transformation through the descriptions of the sheep that become either "lamb" and "mutton" or carcasses strewn on Jake's property in the UK. The sheep are "mangled and bled out, [their] innards not yet crusting and the vapours rising from [them] like steamed pudding" (Wyld 1).

The practice of raising sheep for food and for wool continues to escalate and intensify, despite the growing awareness of the ethical implications of such usage. Those problems are compounded by environmental problems: industrial animal farming significantly contributes to climate change. Yet, the sheep industry has increased its operations by approximately sixty percent since the early $1990 \mathrm{~s}$ ("Sheep"). Today, it is the third largest agricultural industry in the country ("Sheep") and exports more than half (57\%) of the lambs that it kills for consumption as "lamb," $92 \%$ of the sheep that it kills for consumption as mutton, and $8 \%$ of the world's entire lamb and mutton supply. Australia is the largest exporter of sheep meat in the world ("Fast Facts. Australia's Sheep Industry"). ${ }^{4}$ In the southeast state of Victoria alone, sheep number about 15.7 million. That is more than double the 
number of the state's human population. The total population of Australian sheep is about 75.5 million ("Industry Overview"), more than three times of Australia's human population.

The cattle industry has also significantly transformed food in Australia, and unlike the decrease in the number of sheep since the "historical highs" of the 1960s, when the sheep industry was farming 170 million sheep, the number of intensively farmed cattle has not significantly decreased. In the 1970s, the cattle that were farmed for beef were 30 million. Today, they number more than 29 million ("Industry Overview"). The beef cattle industry exports 68\% of the animals that it farms for either "beef" or "veal" and is the third largest beef exporter in the world ("Fact Facts. Australia's Beef Industry"). The dairy cattle industry is smaller but no less a significant player in food transformation in Australia. Although the total number of dairy farms has decreased by more than $50 \%$, "the total value of capital" for those farms has increased by $41 \%$ ("Dairy Industry").

The transformation of milk that associates with intensively farmed cows is one of the most monumental changes in food since the nineteenth century. Cow milk is a commodity that Australia as well as the United Kingdom and the United States have denaturalized and commodified "on a large scale" (Gaard 50). The dairy industries in those countries separate the recognition of milk from the ethical recognition of animals and lead the field in the moral reduction of dairy cows (as well as beef cattle) to something living yet dead (so called livestock). That transformation directly ties to what postcolonial ecocriticism scholars call the "making" of the Global South by the Global North (DeLoughrey and Handley 4). Under that disingenuous material and ideological construction, the Global South is "tradition-shackled" and "hungry" and the Global North is a magnanimous benefactor that liberates and feeds the Global South through "modern, scientific, democratic" and "progressive" practices (19). Those practices, which include the aggressive marketing of meat and milk products, are not fair trade practices; they are venal corporate capitalist enterprises.

The corporate capitalist global dairy industry routinely advertises its products as being "natural" and "wholesome" (Gaard 49). In actuality, its success owes to its hyperbolic exploitation of an animal species. The industry also aggressively promotes its milk products in countries where the majority of the populations are lactose intolerant (51). Claims by the industry that children who drink cows' milk have stronger bones and are taller than children who do not drink cows' milk are unsupported by research to date (51). Those same claims divert attention from the ethical questions surrounding industrial animal farming. In the case of the industrial dairy industry, cows survive only four to five years. Their natural lifespan is twenty to twenty-five years (56). They are artificially inseminated when they are fifteen months old and continually inseminated after that until they can no longer 
produce milk. Dairy industry workers feed the cows bovine growth hormones, which put "enormous pressure" on the cows' bodies; milk the cows two to three times daily using machines that cause painful mastitis and other infections; confine the animals in concrete stalls or force the animals to stand on a "slatted metal floor" for much of their lives; separate the calves from their mothers within hours of the calves' birth, ${ }^{5}$ a separation that is as traumatizing to a mother cow as losing a child at birth is to a female human; and send the male infant offspring to veal farms. Workers at the veal farms confine the young animals in crates that are "so tight" that the animals "cannot move," feed them an iron-deficient diet, and slaughter them at fourteen to seventeen weeks of age" (57). ${ }^{6}$

Mark Bekoff, a former professor of ecology and evolutionary biology, comments that most people in Australia know very little about "the plight of the animals whom they eat" or readily recognize that "when an animal is on a plate, it's a matter of who's for dinner, not what's for dinner," for "factory farmed animals are sentient beings." Feminist scholar Carol Adams famously addressed that concern about twenty years ago under the term "absent referent" in her book The Sexual Politics of Meat. The vast majority of meat eaters do not recognize the suffering and death of the animals they consume and so do not connect their meat meals with the millions of animals that live and die anthropogenically truncated lives in industrial facilities, feedlots, abattoirs, trucks, and shipping containers. Animal justice scholar Cora Diamond also addresses that concern, remarking on the many strategies of distancing, or "deflection," that humans rely on so as not to have to confront the direct links between their meals and animal suffering (56-60).7 Simon C. Estok, in his remarkably audacious and intrepid The Ecophobia Hypothesis, comments on the "cultural attitude of indifference (and inherent contempt)" toward animals that is both invisible and widespread in the present century. Evidence for that, as Estok lays out in detail, includes the "fifty-six billion farmed animals" that societies around the world kill every year (22-23).

We are as unwilling to confront the connections between food transformation and climate change as we are reluctant to confront the ties between food transformation and gross exploitation of animals. The "farm animal sector" is a major cause of global warming and "the single largest anthropogenic user of the land" (Koneswaran and Nierenberg, qtd. in Estok 23). In Australia, greenhouse gas emissions from intensively farmed animals make up about twelve percent of Australia's total greenhouse gas emissions and are the third largest source of agricultural emissions and "nearly equal to all transport emissions" (Bekoff). ${ }^{8}$ We are even less willing to confront the connections between food transformation and climate change when confronted with evidence of political, economic, and social inequities between the Global North and the Global South because of climate change. Climate change is impacting and threatening the Global South more so 
than the Global North. Ninety-eight percent of all climate-change-related human deaths occur in regions of the Global South (DeLoughrey and Handley 26). The most "closely related outcomes" of climate change, in addition to deforestation, are rapid urbanization, and "inequitable international trade regimes," "food insecurity" (Lousely 247). It directly correlates with the transformation of food by corporate capitalist food giants that started up in the West and Global North (247).

Estok critiques the links between the meat industry and climate change thus: "to presume...to consider climate change without analysing the meat industry...is nothing short of hollow talk and hypocrisy" (78). Elaborating on that indictment in the chapter in The Ecophobia Hypothesis entitled "Animals, Ecophobia, and Food," Estok analyzes the connections between "the global livestock industry," "class ascension," and "the violence of capitalism as world ecology" (93). He ties that to his main argument about the lack of conversation around ecophobic attitudes toward and treatment of the environment and animals. Those attitudes pose complex and difficult but not insurmountable problems. To confront them means both challenging "a vast economic machine" and attracting considerable anger, animosity, and indignation from people not willing to consider the relationship between food and animals (93).

Few Australians, myself included, have any comprehensive knowledge of food production in Australia before 1788, which was largely plant-based. Merlinda Bobis's cli-fi novel Locust Girl, winner in 2016 of the Christina Stead Prize for Fiction and New South Wales Premier's Literary Award, alludes to that history. ${ }^{9}$ Through its fictional figures, the rulers of the "Five Kingdoms," Bobis obliquely questions the post-1788 governance of Australia and the role that its political elite have played in food transformation since that fateful year. The novel follows the misfortunes of a hybrid human-insect whose country has been devastated by fire and drought generated by the rulers of "Five Kingdoms." Amedea, a young girl, ekes out an existence with her father and mother in one of the "missions" that lie outside of the borders of the Five Kingdoms (Bobis 152). She, her family, and the other traditional custodians of the country, survive by feeding on "sand porridge and locust" (3). Amedea is one of the only survivors of the fire that the rulers of the Five Kingdoms set to her country. She hibernates deep below the surface of the earth. Another lone survivor, a locust, also manages to escape the inferno. "Trapped" and "confused," it initially mistakes Amedea for a stone that "block[s] its way" (9). It first "nibble[s]" at the burnt crust of Amedea's skin and then attaches itself to Amedea, burying itself in her forehead (9). Ten years later, the nineteen-year old hybrid human-insect "Locust Girl" is discovered by Beenabe, a sixteen-year old girl from a neighboring country. Like Amedea's country, Beenabe's country is controlled by the rulers of the Five Kingdoms. The Five Kingdoms government makes few distinctions between the many countries that it is steadily wiping out under a double program 
of genocide and ecocide. ${ }^{10}$ The only large animal species that remain in the wild is the "guri." The Five Kingdom rulers use the guri solely as a product for human consumption and employ migrant workers, mostly women whose countries have been destroyed by the Five Kingdoms, to kill the guri in massive organized culling operations.

The descriptions of "guri," the only animals that appear in the novel (with the exception of a lone surviving locust), satirize the commercial culling ${ }^{11}$ of kangaroos in Australia and the tolerating of their existence because of a newfound commodity value. The rulers of the Five Kingdoms slaughter the guri for their "amber fur" and meat (Bobis 95; 119). No other large animal species are permitted to exist. The plight of the guri mirrors that of the kangaroos and wallabies in Australia that the government and the meat industry permit to exist on morally defunct grounds. The "commercial kill of kangaroos for meat and leather" is "the largest consumptive mammalian wildlife industry in the world" (Boom et al. 18). Annually, the industry kills an average of three million adult kangaroos on land that constitutes "nearly three quarters" of Australia's continental mass (18). In addition to the hides that the industry sells to consumers, it sells the carcasses of the animals for use as either pet meat or meat for human consumption (18). Every year, the industry also kills approximately one million joeys because of a "national code of practice" that dictates that a joey must "be killed alongside" its mother (18).

The two most frequently cited rationales against halting kangaroo slaughter are that the animals "compete with livestock for resources throughout the rangelands of Australia" and that their numbers are increasing "because of the installation of artificial waterholes" (Boom et al., 19). Opponents of the industry challenge those findings, pointing to a paucity of evidence and calling for a reassessment of the industry both because of its large negative impact on the ecosystem and because of ethical questions about kangaroo welfare (17).

Locust Girl also carries implicit references to the virtually unknown history of the disappearance of vast Australian grain belts and the increasing separation of moral bonds from vegetal life. Amedea ("Locust Girl") and Beenabe desperately search for local grain that has not been destroyed by the rulers of the Five Kingdoms. Amedea has never seen "green." Years before, she asks her father about "trees" (4). Like the color green, trees represent the vegetal life that Amedea has never seen.

'...what's trees, Father?'

'Tall things with leaves.'

'What's leaves?'

'Green things.'

'What's green?'

Kritika Kultura 33/34 (2019/2020): 627-640

(C) Ateneo de Manila University

<http://journals.ateneo.edu/ojs/kk/> 
My father frowned deeply to squeeze from his brow the apparition of trees for me. 'Green was tall and proud.' (4)

Older people remember the time before the rule of the Five Kingdoms, when their countries were filled with color. They remember the word "green" with the greatest sense of loss. They attempt to preserve the memory of it in the stories they tell about their people and country:

'Red', the first mouth whispered to the second ear, who whispered back, 'Red flowers', and then passed on the next colour to the third in line: 'Orange.'

'Orange birds', the third mouth whispered back and, to the fourth, passed on: 'Blue.'

'Blue sky,' the fourth mouth whispered back and, to the fifth, passed on: 'Yellow.'

'Yellow fields', the fifth mouth whispered back and, to the last, whispered: 'Green.'

All grew silent. (Bobis 64)

Before 1788 , human populations coexisted and worked with vegetal communities across the continent. Humans lived and thrived with those communities on relatively balanced ethical and material terms. Today, Australia's human populations congregate in one of five main "grey" anthropogenic environments (Sydney, Melbourne, Perth, Brisbane, and Adelaide), and the government promotes over-farming and over-mining of the country's oldest environments. The rationale for such usage is that human populations today are significantly larger than they were before 1788 and so intensive agriculture and mining are necessary. What that argument misses is that the oldest Australians gave far more moral recognition to the rights of animals, plants, and the environment than we do today and so did not seek to overrun or hyper-manage those beings and ecosystems (Gammage; Pascoe). It is a kind of control that reminds one of fascist governments and absolute monarchies, economic and political forms of government that democratic societies supposedly will not tolerate. What that same argument also hides is that hunger today, among the planet's 7.6 billion humans, is a problem of food "distribution" not food scarcity (Gaard 133). Apparently, it is not being solved by the current corporate capitalist control of food production and distribution.

Before 1788 , food production based on plants-namely grain production-was locally managed and controlled by women. Until recently, anthropologists and archeologists knew little about this. Nor did they know about the extent and sophistication of agriculture in Australia. The reasons tie to chauvinist attitudes as well as to racism and colonialism. In the past, archeologists were unable to learn (or not interested in learning) about the role that women played in agriculture (Pascoe 62). Indigenous studies scholar Bruce Pascoe makes such an argument in Dark Emu. Black Seeds: Agriculture or Accident? Referring to recent work that focuses on both North American and Australian ancient cultures, Pascoe points 
out that previous studies invariably found that the people of those cultures were, at best, "complex hunter-gatherers" and, at worst, "wealthy scavengers" who were "incapable of the sophisticated cultural development associated with agricultural societies (61). In the case of Australia, as late as the 1980s, studies of grain production by anthropologists and archeologists failed to mention "the vast scale of grain harvests" because the custodians of that knowledge were women. They either were not asked to impart their knowledge or were unwilling to do so because of the experience of being exploited for that knowledge (64).

It is still "rare to come across a text...that describes the existence of intensive Aboriginal food production," which included "fishing systems" as well as "grain and tuber production" (Pascoe 64). ${ }^{12}$ Instead, countless "common plaster figurines of Aboriginal men standing on one leg, spear in hand waiting for the windfall kangaroo" attest to much of our knowledge of indigenous food production (65). Masculinist models of food production and patriarchal global food giants have transformed food. The latter hyper-regulate and over-determine plant agencies and so virtually completely disregard the who-ness of plants, or the ethical bonds between humans and "earthothers" (Gaard 22). Locust Girl's Five Kingdoms' rulers evoke those practices and the corporate food giants who most engage in and promote them. Bobis's fictional rulers divvy up, commodify, and privatize plant life. One oversees the earth's "colors," a second controls the earth's oils, a third supervises water supplies, a fourth (mis)manages fire, and a fifth oversees the distribution of grain ("seeds"). The rulers explain that it is "For symmetry. For equality. For justice" (Bobis 150). It is blatantly false rhetoric. It evokes such global food giants as Monsanto. An especially abominable practice of Monsanto refers to the sterilization of seeds. The company engineers seed stock that carries biological mechanisms, "terminator technologies," to make the stock sterile (Stein 183). Another practice refers to the policy of not allowing farmers to use viable leftover seed for the next planting season. In the case of Monsanto, farmers must purchase new seed stock from the company, and at prices that Monsanto dictates (183). Yet, Monsanto defends its right to destroy "plant reproductive capacities so that neither farmers nor plants have access to free propagation outside of market property arrangements" (183). Its bioengineered seeds also destroy other seeds, cross-pollinating with crops that are not bioengineered that are adjacent to crops carrying Monsanto's seeds. Yet, the rhetoric of Monsanto, like that of the Honorable Head in Locust Girl, is that it offers ideal solutions for ethical, sustainable food production in the world today. ${ }^{13}$

As Greta Gaard argues in Critical Ecofeminism, an exhaustive summary and complex analysis of the inception, history, and current status of ecofeminism, global food giants also have transformed food through debt repayment programs, euphemistically called "structural adjustments" (132). Those require in effect that "developing countries produce cash crops for export rather than food crops 
for subsistence as a way to pay off debt" (132). They have profoundly displaced older modes of food production, undermined efforts of "small-scale farming and community gardens," and effectively ignored the affective entanglements that ethically bind humans and other animals to each other (138). Other common practices by transnational food companies similarly play havoc with the interlocking of "species justice, environmental justice, reproductive justice and food justice" (132).

Locust Girl alludes to food transformation in Australia today that refers to the destruction of interspecies bonds between humans and animal and plant life. It does that through, among other characters, the eponymous hybrid human-insect "Locust Girl." The locust and the young woman are not combatants. Their joined bodies represent the acceptance of and willingness to share the earth with other species. Their moral flight path markedly contrasts with the path forged by the rulers of the Five Kingdoms. The rulers join forces for the purpose of controlling not coexisting with other species; and they tacitly accept that the most aggressive competitor has the right to monopolize the agencies, interests, and powers of all other species and the vast majority of humans. That kind of monopolizationhuman, animal, and environmental hegemony_took place in Australia after 1788. Before that time, even the driest inland areas of Australia were clothed knee-deep in grasslands for many months of the year. People cultivated and worked with those grasslands and their many species of smaller or larger animals inclusive of winged insects. The grasslands included extensive grain belts across the length and breadth of the continent; they sustained and were supported by people on the basis of sophisticated affective, ethical, and material terms (Pascoe 29). The grains included Coopers clover (Trigonella sauvissima); barley grass or native millet (Panicum decompositum), also called cooly or parpar; onion grass (Cyperus bubosus); nardoo (Marsilea drummondii); fig; quandong; Australian banana (Musa acuminate, subspecies Banksii); compung (Cumbungi); balyan or bulrush; yam daisies (Microsceris lanceloata); Vanilla Lily (Arthropodium milleflorum), a staple source, like the yam daisies, of starch and protein in Eastern Victoria; Curly Mitchell grass (Astraleba lappacea); and native oatgrass (Themeda avanacea) (Pascoe 32, 33, $44,45,46,51,119-120,146)$. Today, most of those grains have disappeared, and crops that now are grown are mostly concentrated in the southwest and southeast of Australia (29). The majority are unsustainable commodity crops. Foremost among them is wheat.

Australia is the eighth largest producer and fourth largest exporter of wheat in the world. Wheat is the most common (cereal grain) crop cultivated in Australia and throughout the rest of the world ("Wheat"). "In the space of a century," between the early twentieth and twenty-first centuries, "wheat yields...increased [globally] from about four hundredweight per acre...to an average of thirty-two hundredweight" 
(Robin 309). To achieve what turned out to be relatively short term outcomes with long term deleterious impacts, agribusinesses increased their use of "phytosanitary products" and fertilizers (such as nitrogen, phosphorous, and potassium), which caused "a decline in the natural fertility of the soil" (309). They also used massive amounts of insecticides and fungicides because of the "extreme vegetal density" of the environments that they had created (309).

Agribusiness has "not produced more food," as Vandana Shiva argues (qtd. in Estok 95). Instead, it has transformed and "stolen food from other species to bring larger quantities of specific commodities to the market, using huge quantities of fossil fuels and water and toxic chemicals in the process" (Shiva qtd. in Estok 95). If Australia's original people "did jar the land's regenerative capacity, imbalances were slight and their threat remote. What came after 1788 was much more serious. Damage then was ignorant rather than willful, but revolutionary" (Grammage 313). Newcomers "ran big mobs of sheep on pasture that was never going to last the next dry period; put cattle on fire-prone forest hillsides; and cleared land to plant [introduced] grain crops in thin, nutrient-poor soils that took off and blew away when the rains stopped altogether" (Rigby 120). Regions of Australia that now are desolate "Outback" once were productive and healthy environment[s] for large numbers of Aboriginal people" (Pascoe 77). Even the most inland deserts and other infamous areas for European explorers were "peopled by large numbers" of Australians, who took advantage of the plains to manage "flood dispersal, plant crops, and harvest and store grain" (76-77). ${ }^{14}$ Yet, the "tenacity of...delusion" about Aboriginal people that traces back to the colonial period continues to "[impoverish] national debate" in Australia today (77). We barely raise an eyebrow at the ongoing eradication of green space in country areas. The small scraggly and thirsty-looking town parks and the relatively small area of land set aside for national parks do not measure up against the vast tracts of land used for the food transformation wrought by intensive agriculture.

In the conclusion of his study, The Biggest Estate on Earth: How Aborigines Made Australia, Bill Gammage writes:

There is no return to 1788 . Non-Aborigines are too many, too centralized, too stratified, too comfortable, too conservative, too successful, too ignorant. We are still newcomers, still in wilderness.... We use land care merely to mitigate land misuse. We champion sustainability, which evokes merely surviving, whereas in 1788 people assumed abundance.... When the time comes to choose between parks and people, species and space, food and freedom, 1788's values will be obliterated. (321)

A little later, he writes, 
If terra nullis exists anywhere in [Australia], it was made by Europeans...an ancient philosophy was destroyed by the completely unexpected, an invasion of new people and ideas. A majestic achievement ended. Only fragments remain. For the people of 1788 , the loss was stupefying. For the newcomers, it did not seem great. Until recently few noticed that they had lost anything at all. (323)

Gammage mentions an infamous term that Anglo-European colonizers used to describe Australia in 1788: terra nullis, or empty land. Australia was not empty from the perspective of people living in Australia before the eighteenth century. Based on testimonies by descendants of those Australians and arguments by scholars of indigenous studies and environmental history, Australia became "empty" after that time, when newcomers progressively laid waste to the continent and its oldest people (Gammage 323). Today, "the parks have gone," "[t]he earth has changed," and "[t]opsoil blows away, hills slip, gullies scour, silt chokes, salt spreads, soil compacts" $(17 ; 103)$. Unlike cattle and sheep, the large Australian animals of kangaroos, wallabies, and other "grazer species" did "not break up the surface of the soil-or compact it-both of which lead to erosion" (Pascoe 43). As a direct consequence of food transformation inaugurated and accelerated by the farming of sheep and cattle, Australia today is "a world leader in animal and plant extinction" (Gammage 320). ${ }^{15}$

The "absolute nonchalance towards nature's non-human bodies...desecrated in the industrial-meat industry" (Estok 92), and the "meatification" (Weis 150) of Australian diets, which mirror global diets, must be addressed in conversations about the post-eighteenth century transformation of food. Instead, and too often, we avoid considering the staggering numbers of exploited animals and environments that define the contours of food production today, a transformation to which corporate capitalist industrial food giants have given monstrous birth.

Food is often bound up with violence, but multinational food companies have grossly accelerated and intensified that violence under a false rhetoric of necessity. They are doing so mainly for profit. To continue to profit, they have made the specific forms of violence they engage in increasingly invisible and inaccessible to-under recently introduced Ag-gag laws-the public. ${ }^{16}$ Violence is the basis of food transformation today. So, how can literature and art help us to conceptualize and deal with this violence?

Ecocriticism and globalization studies scholar Ursula Heise muses on precisely this question in her discussions about "what the function of the literary text might be for areas of literary and cultural study that are intimately connected to broader political projects and movements" (258). Yes, there are "more straightforward 
places" than literature for finding out about those projects and movements (258). Investigative journalism, political commentary, and documentary film represent some of those places (258). They emphasize "factual accuracy" more than aesthetic play (258). Nonetheless, "the aesthetic transformation of the real has a particular potential for reshaping the individual and collective ecosocial imaginary" (258). That kind of transformation "[deserves] our...attention" as much as actual "cultural... [and] biological structures" (258). Bobis's Locust Girl and Wyld's All the Birds, Singing represent the reimagining of "the real" as that specifically refers to the violence that is the basis of food transformation. Both novels subtly critique the transformation in the context of the animals that Australians intensively slaughter and the sustainable agricultural practices that they obliterated after 1788 . Euphemistically called Australian pastoral, intensive animal slaughter and ecocide in Australia mirror commercial and masculinist corporate capitalist pastoral enterprises elsewhere. Those enterprises endorse and depend utterly on negating moral bonds between human and nonhuman animal and vegetal life. If people are to redefine "the individual and collective ecosocial imaginary" (Heise 258), then they must recognize that food is inseparable from ethics and that ethics includes how we relate to animals and the environment. Locust Girl and All the Birds, Singing, in addition to books published in indigenous studies, animal studies, ecocriticism, ecofeminism, and environmental history, ${ }^{17}$ are key to recognizing the ethical bonds between people, animals, and the environment and for understanding food transformation in Australia. 


\section{Notes}

1. For ecocritical perspectives on the origins of pastoral in western European literary and cultural contexts, see Casteel; Huggan and Tiffin; and Pughe, Chorier-Fryd and Holdefer. For more on pastoral in Australian literary contexts, see Lynch ("Pastoralism").

2. See, also, Ruth Blair's "Hugging the Shore: The Green Mountains of Southeast Queensland." The author writes about several nineteenth-century pastoralists who were unusually sensitive to the negative impact of pastoral enterprises and ended up working on the other side of the fence of attitudes toward pastoral and so seeking to preserve some of the land they had once seen only in instrumentalist economic terms.

3. Jake avoids killing sheep, but she shears sheep, and sheep shearing, or the wool industry, which in Australia produces about thirty percent of the world's wool ("Wool"), is as much a site of violence as the mutton and lamb trade in Australia. In 2017, an undercover surveillance film of sheep shearing sheds in New South Wales and Victoria, Australia's top two wool producing states, showed male shearers routinely violently punching sheep in the face, beating them with metal tools, slamming their heads into the floor, kicking them, and "leaving them unconscious" (Salemme). Those sheep, and other breeds that are commonly farmed for the products of mutton and lamb, are bred for their gentleness. They "are petrified of even being held down" but are not given the kinds of moral consideration that we legislate to give to members of our own species (Salemme).

4. Due largely to the efforts of animal activists in Australia, foremost among whom are members of Animals Australia, the government has halted the export of live sheep and it is likely that a permanent ban will be put into effect (Remeikis).

5. See Flower and Weary; and Marino and Allen.

6. For a full summary of the nefariously unethical practices of the milk industry, see Gaard (49-68).

7. See, also, animal studies scholar Peter Chen's Animal Welfare in Australia: Politics and Polity.

8. For the specific connections between greenhouse gas emissions and cows that are farmed as a source of dairy products, see Ormond.

9. Cli-fi is a new genre that has exploded since Dan Bloom, a freelance journalist based in Taiwan, first coined the term "cli-fi" (Estok 59). Bloom uses the term to distinguish any fiction that foregrounds "environmentalism and climate change issues." Adam Trexler and Adeline Johns-Putra, cli-fi literature scholars, describe cli-fi as a sub-genre of sci-fi that replaces off-the-planet settings with earthly venues, reflects interest in "the relationship between climate change and humanity in psychological and social terms," and represents climate change "not just as a meteorological or ecological crisis 'out there' but as something that is" vitally connected to the human and "filtered through our inner and outer lives" (196).

Kritika Kultura 33/34 (2019/2020): 634-640

(C) Ateneo de Manila University

<http://journals.ateneo.edu/ojs/kk/> 
For more on cli-fi, and for a useful introduction to cli-fi in ecocritical contexts, see Trexler.

10. Sophie Christman, in the Foreword to Estok's The Ecophobia Hypothesis, introduces Estok's use of the term (ecophobia) as "a unique human form of ecosuicide" that undermines "humanity's self-preservation in its own environment" (xii). All three terms, "eco-suicide," "ecophobia," and "ecocide," are relevant to this article.

11. "Culling" is the euphemistic way to avoid the realities of what is really going on: "culling" sounds much better than "mass slaughter." Kangaroo meat is a major food export that has demonstrated the change in the status of the kangaroo from that of a "pest" to a "resource," a dubious transition at best in moral terms (Boom et al.)

12. For more on the control and eradication of Australia's oldest people through food production policies, see Elspeth Probyn's "Entanglements: Fish, Guts, and Bio-cultural Sustainability." Probyn comments on the "enormous discrepancy in Type 2 diabetes rates amongst Aboriginal and non-Indigenous Australians" in her argument that food production in Australia plays a significant role in that discrepancy (290). Probyn also comments on the relationship between a population of Australians that represents the "highest percentage of millionaires per capita" in Australia and the highly industrialized Southern Bluefin Tuna fish farming industry (295). See, also, Tim Rowse's study entitled White Flour, White Power, a critique of "the dehumanization of Aboriginals" through systems of food rationing and other strategies that reduced "Aboriginal people in status as well as in sheer numbers - through genocide" (290).

13. The most comprehensive critique of Monsanto is by Marie-Monique Robin, a work cited in this paper.

14. Aquaculture also was extensive and sophisticated. The people of 1788 harvested abalone-derogatively called mutton fish by newcomers-along Australia's coast from the south of Perth, "across the southern coast including Tasmania and her islands, west to Gippsland in eastern Victoria and north to Wollongong in New South Wales" (Pascoe 86). In southwest Victoria, Aboriginal people constructed "vast eel concourses" that took "centuries to refine" (55). They are as significant as Stonehenge or the Easter Island (6o). The majority of Australians today are unaware of, and the government does not bother to educate them about, that illustrious heritage. Exacerbating that is the fact that the people who came to Australia after 1788 destroyed most of the concourses in the first days after their arrival, along with people's entire villages, which the newcomers burned to the ground (6o).

15. In "Animals and Ecology: Towards a Better Integration," the sixth chapter of Val Plumwood's posthumous The Eye of the Crocodile, Plumwood comments on the transformation of food since the nineteenth century-namely, the decline of plant-based and increase of meat-based diets. Nonetheless, Plumwood criticizes vegan challenges to that food transformation. She characterizes those challenges as constituting an "ontological veganism" position. That position, as she argues, misguidedly reinforces the "human/animal" dualism because it puts the human 
species outside of the food chain-"outside nature"-and so denies the human species, a predatory species, a rightful ecological place (79). That same position wrongfully insists that "neither humans nor animals should ever be conceived as edible or even as usable" and so re-enacts a false "human/nature dualism" (78). Further, it betrays a "highly ethnocentric" bias, legitimizing a privileged Western consumer's perspective and treating all other perspectives as "minor, deviant 'exceptions' to what it takes to be the ideal or norm" (78-79). The "ecological animalism" versus "ontological veganism" argument that Plumwood sets up is an unfair opposition and is a cheap shot at vegans (and vegetarians). It reduces those food consumers to a one-size-fits-all "ontological veganism" group and implies that meat eaters hold diverse and complex ethical positions around meat eating. Nonetheless, in fairness to Plumwood's argument, it highlights the most morally reprehensible aspects of meat production today.

16. See Ralph.

17. Plant studies is a burgeoning area of inquiry that I do not cover here although it closely relates to the concerns of this article. For recent work in that area, see Joni Adamson's "Plants and Literature: Essays in Critical Plant Studies"; John Ryan, Monica Gagliano, and Patricia Vieira's edited The Language of Plants: Science, Philosophy, and Literature; and Michael Marder's series edited Critical Plant Studies: Philosophy, Literature, and Culture. 


\section{Works Cited}

Adams, Carol J. The Sexual Politics of Meat (20 ${ }^{\text {th }}$ Anniversary Edition) Feminist-Vegetarian Critical Theory. Continuum, 2010.

Adamson, Joni. "Plants and Literature: Essays in Critical Plant Studies." ISLE, vol. 21, no. 14, 2014, pp. 710-712.

Bekoff, Mark. "Who are you eating? That is the question." The Sydney Morning Herald, 22 Feb. 2013. smh.com.au/environment/animals/who-are-youeating-that-is-the-question20130222-2etyr.html. Accessed 27 Sept. 2018.

Blair, Ruth. "Hugging the Shore: The Green Mountains of Southeast Queensland." The Littoral Zone: Australian Contexts and Their Writers, edited by CA Cranston and Robert Zeller, Rodopi, 2007, pp. 177-197.

Bloom, Dan. 'Cli-fi' all the rage among literati and academia." Taipei Times, 12 July 2013. taipeitimes.com/News/editorials/archives/2013/07/12/200356690o. Accessed 22 Nov. 2018.

Bobis, Merlinda. Locust Girl. Spinifex P, 2015.

Boom, Keely, Dror Ben-Ami, David B. Croft, Nancy Cushing, Daniel Ramp, and Louise Boronyak. "Pest' and Resource: A Legal History of Australia's Kangaroos." Animal Studies Journal, vol. 1, no. 1, 2012, pp. 17-40. ro.uow.edu.au/asj/vol1/iss1/3/.

Calarco, Matthew. Zoographies: The Question of the Animal from Heidegger to Derrida. Columbia UP, 2008.

Casteel, Sarah Phillips. "Pastoral." Keywords for Environmental Studies, edited by Joni Adamson, William A. Gleason, and David N. Pellow, New York UP, 2016, pp. 158-161.

Chen, Peter. Animal Welfare in Australia: Politics and Polity. Sydney UP, 2016.

Christman, Sophie. Foreword. The Ecophobia Hypothesis, by Simon C. Estok, Routledge, 2018, pp. ix-xvi.

Cranston, CA, and Robert Zeller, editors. The Littoral Zone: Australian Contexts and Their Writers. Rodopi P, 2007.

"Dairy Industry." Australian Government. Department of Agriculture and Water Resources." agriculture.gov.au/abares/research-topics/surveys/dairy. Accessed 26 Feb. 2019.

DeLoughrey, Elizabeth, and George B. Handley. "Introduction: Toward and Aesthetics of the Earth." Postcolonial Ecologies: Literatures of the Environment, edited by DeLoughrey and Handley, Oxford UP, 2011, pp. 3-39.

DeLoughrey, Elizabeth, Jill Didur, and Anthony Carrigan, editors. Global Ecologies and the Environmental Humanities. Routledge, 2015.

Diamond, Cora. "The Difficulty of Reality and the Difficulty of Philosophy." Philosophy and Animal Life, Columbia UP, 2008, pp. 43-89.

Estok, Simon. The Ecophobia Hypothesis. Routledge, 2018.

"Fast Facts. Australia's Beef Industry." Meat and Livestock Australia. mla.com.au/about$\mathrm{mla} /$ cattle-sheep-goat-industries/industry-overview. Accessed $27 \mathrm{Sept} .2018$.

"Fast Facts. Australia's Sheep Industry." Meat and Livestock Australia. mla.com.au/aboutmla/cattle-sheep-goat-industries/industry-overview. Accessed 27 Sept. 2018. 
Flower, Frances C., and Daniel M. Weary. "Effects of Early Separation on the Dairy Cow and Calf: 2. Separation at 1 Day and 2 Weeks after Birth." Applied Animal Behaviour Science, vol. 70, no. 4, 2001, pp. 275-284. doi: 10.1016/So168-1591(oo)oo164-7.

Gaard, Greta. Critical Ecofeminism. Lexington, 2017.

Gammage, Bill. The Biggest Estate on Earth: How Aborigines Made Australia. Allen and Unwin, 2011.

Heise, Ursula. "Afterword. Postcolonial Ecocriticism and the Question of Literature." Postcolonial Green Environmental Politics and World Narratives, edited by Bonnie Roos and Alex Hunt, U of Virginia P, 2010, pp. 251-258.

Huggan, Graham, and Helen Tiffin. "Pastoral in Black and White." Postcolonial Ecocriticism: Literature, Animals, Environment, Routledge, 2010, pp. 85-95.

"Industry Overview." Meat and Livestock Australia. mla.com.au/about-mla/cattle-sheepgoat-industries/industry-overview. Accessed 28 Sept. 2018.

Kinsella, John. Contrary Rhetoric: Lectures on Landscape and Language, edited by Glen Phillips and Andrew Taylor, Fremantle P, 2008.

Koneswaran, Gowri, and Danielle Nierenberg. "Global Farm Animal Production and Global Warming" Impacting and Mitigating Climate Change." Environmental Health Perspectives, vol. 116, no. 5, 2008, pp. 578-582. animalstudiesrepository.org/acwp_ faafp/19/. Accessed 3 Oct. 2018.

Lousley, Cheryl. "Narrating a Global Future." Global Ecologies and the Environmental Humanities, edited by Elizabeth DeLoughrey, Jill Didur, and Anthony Carrigan, Routledge, 2015, pp. $245-267$.

Lynch, Tom. "Pastoralism." The Littoral Zone: Australian Contexts and Their Writers, edited by CA Cranston and Robert Zeller, Rodopi, 2007, pp. 72-76.

Marder, Michael, series editor. Critical Plant Studies: Philosophy, Literature, and Culture. Brill-Rodopi, 2017.

Marino, Lori, and Kristin Allen. "The Psychology of Cows." Animal Behavior and Cognition, vol. 4, no. 4, 2017, pp. 474-498. dx.doi.org/10.26451/abc.04.04.06.2017.

Ormond, Jim. "The Transition to Low Carbon Milk: Dairy Consumption and the Changing Politics of Human-Animal Relations." Why We Eat, How We Eat: Contemporary Encounters between Foods and Bodies, edited by Emma-Jayne Abbots and Anna Lavis, Ashgate, 2013, pp. 187-207.

Pascoe, Bruce. Dark Emu. Black Seeds: Agriculture or Accident? 2014. Magabala Books, 2016.

Plumwood, Val. The Eye of the Crocodile, edited by Lorraine Shannon, Australian National University E-Press, 2012. epress.anu.edu.au/titles/the-eye-of-the-crocodile.

Probyn, Elspeth. "Entanglements: Fish, Guts, and Bio-cultural Sustainability." Why We Eat, How We Eat: Contemporary Encounters between Foods and Bodies, edited by EmmaJayne Abbots and Anna Lavis, Ashgate, 2013, pp. 289-300.

Pughe, Thomas, Benedicte Chorier-Fryd, and Charles Holdefer, editors. "Pastoral: Past, Present, Future" (special issue). Green Letters: Studies in Ecocriticism, vol. 20, no. 1, 2016, pp. 1-118. 
Ralph, Iris. "Australian Tongue and Ag-gag Law." AJE: Australasian Journal of Ecocriticism and Cultural Ecology, vol. 6, 2016, pp. 50-61, openjournals.library.sydney.edu.au/index. php/AJE/index.

Remeikis, Amy. "Labor promises to ban live sheep exports and have meat processed in Australia." The Guardian, 2 May 2018, theguardian.com/australia-news/2018/may/o3/ labor-promises-to-ban-live-sheep-exports-and-have-meat-processed-in-australia. Accessed 6 Dec. 2018.

Rigby, Kate. Dancing with Disaster: Environmental Histories, Narratives, and Ethics for Perilous Times. U of Virginia P, 2015.

Robin, Marie-Monique. The World According to Monsanto: Pollution, Politics and Power. Translated from the French by George Holoch. Spinifex P, 2010.

Roos, Bonnie, and Alex Hunt, editors. Postcolonial Green Environmental Politics and World Narratives. U of Virginia P, 2010.

Rowse, Tim. White Flour, White Power: From Rations to Citizenship in Central Australia. Cambridge UP, 1998.

Ryan, John, Monica Gagliano, and Patricia Vieira, editors. The Language of Plants: Science, Philosophy, and Literature. U of Minnesota P, 2017.

Salemme, Nadia. "Sickening' Australian wool practices revealed in new PETA footage." News.Com.Au, 14 Dec., 2017, news.com.au/lifestyle/fashion/sickening-australian-woolpractices-revealed-in-new-peta-footage/news-story/7646f795ca1b22e831017b4df875 73d6. Accessed 10 Nov. 2018.

"Sheep." Department of Economic Development, Jobs, Transport and Resources, Sheep / Livestock / Agriculture / Agriculture Victoria, 10 Nov. 2017, agriculture.vic.gov.au/ agriculture/livestock/sheep. Accessed 28 Sept. 2018.

Shiva, Vandana. Stolen Harvest: The Hijacking of the Global Food Supply. Southend P, 2000.

Stein, Rachel. "Bad Seed: Imperiled Biological and Social Diversity in Ruth Ozeki's All Over Creation." Postcolonial Green Environmental Politics and World Narratives, edited by Bonnie Roos and Alex Hunt, U of Virginia P, 2010, pp. 177-193.

Sullivan, Heather I. "Dirty Traffic and the Dark Pastoral in the Anthropocene: Narrating Refugees, Radiation, Deforestation, and Melting Ice." Literatur für Leser, vol. 14, no. 2, 2014, pp. 83-97.

--. "Nature and the 'Dark Pastoral' in Goethe's Werther." Goethe Yearbook, vol. 22, 2015, pp. 115-132.

Tredinnick, Mark. "Under the Mountains and Beside a Creek: Robert Gray and the Shepherding of Antipodean Being." The Littoral Zone: Australian Contexts and Their Writers, edited by CA Cranston and Robert Zeller, Rodopi, 2007, pp. 124-143.

Trexler, Adam. "Mediating Climate Change: Ecocriticism, Science Studies, and The Hungry Tide." The Oxford Handbook of Ecocriticism, edited by Greg Garrard, Oxford UP, 2014, pp. 205-224.

Trexler, Adam, and Adeline Johns-Putra. "Climate Change in Literature and Literary Criticism." WIREs ClimChange, vol. 2, 2011, pp. 185-200. researchgate.net/ publication/230451233_Climate_change_in_literature_and_literary_criticism. doi: $10.1002 /$ wcc. 105 . 
Weis, Tony. The Ecological Hoofprint: The Global Burden of Industrial Livestock. Zed Books, 2013.

"Wheat." Grains E Legumes Nutrition Council. glnc.org.au/grains/types-of-grains/wheat/. Accessed 27. Sept. 2018.

"Wool." Veganpeace.com. veganpeace.com/animal_cruelty/wool.htm. Accessed 27 Sept. 2018.

Wyld, Evie. All the Birds, Singing. Jonathan Cape, 2013. 